\title{
Causation, Capacities, Flow, Initiative and Power in the Economic System
}

\author{
Michael Joffe \\ Department of Epidemiology and Biostatistics, Imperial College London, Norfolk Place, United Kingdom
}

Copyright $(2018$ by authors, all rights reserved. Authors agree that this article remains permanently open access under the terms of the Creative Commons Attribution License 4.0 International License

\begin{abstract}
Natural sciences such as biology and geology are characterised by empirically-based causal theories, which were developed by iteration between evidence and causal ideas. Economics could benefit from applying a similar methodology, given that it seeks to explain a similarly complicated, heterogeneous and open-ended reality. Causal accounts that correspond with the real world would replace "as if" theories, and the practice of seeking to explain the deviation of observed phenomena from standard theory rather than the phenomena themselves. As in those natural sciences, theory would be based on capacities - taking account of the human characteristics of interaction, incentive-following and initiative - and on flows and stocks, especially buying power (income and wealth). More generally, causal theories in economics should focus on power, in the sense of the ability to bring something about. This especially applies to the firm's authority structure (legitimate power), which arises from its ability to pay its workers, but more fundamentally, to successful investment initiative. Finally, human interaction needs to be incorporated, in the form of system causation. The "price mechanism" is one example, and there are other important examples of systems that display feedback, e.g. bubbles, as well as complexity.
\end{abstract}

Keywords Economic Methodology, Causal Theory, Agency Causation, Economic Power, Capacities, Flows, Stocks, System Causation

JEL codes: B41 Economic methodology

\section{Introduction}

The natural sciences have proven highly successful in developing causal theories that explain important aspects of how the world works. In some cases, these causal theories are also useful in making predictions. Many of the natural sciences, such as biology and geology, investigate a complicated, heterogeneous and open-ended reality, much like the economy. Economists may be able to learn useful lessons from some of the methodologies used by scientists in these disciplines.

This focus is complementary to the more traditional concern of economic methodology with analysis of models, e.g. whether they contain - or can in principle contain true statements about the real world [1], and the extent to which they can provide explanations [2-10].

There is an important precedent for this approach. Marshall suggested that "The Mecca of the economist lies in economic biology" [11, p. xii], on the basis that "economics, like biology, deals with a matter, of which the inner nature and constitution, as well as the outer form, are constantly changing" [11, p. 637]. This position is stronger today, given that the biological sciences have progressed enormously since Marshall's day.

In this paper, I draw on the conclusions derived from three previously-published case studies, on the germ theory of disease, the circulation of the blood in humans, and continental drift/tectonic plate theory [12]. These are methodological lessons, the intention is not to import causal categories from other domains, as has already become a feature of some work in evolutionary economics.

\section{Causation in the Natural Sciences}

The three previous case studies were all instances of empirically-based causal theories, which is a characteristic feature of knowledge generation in these sciences [12]. In this context, the term "theory" denotes a very different entity from its usual meaning in economics, where it tends to indicate a model, a group of models, or a modelling approach, typically based on axioms and/or assumptions and involving mathematics, accompanied by a "story" [13].

In these natural sciences, a theory is primarily orientated towards causal explanation, aiming to show how a real-world phenomenon works, rather than prioritising prediction as economic theory often does. It aims to explain all aspects of the phenomenon - its diverse range of features together with the causal forces that bring them about. Central to this is to elucidate how these forces work, phrased in the language of capacities [14] or mechanisms the composition/structure of entities, and their activities $[15,16]$.

An important feature here is that the aim is to describe the whole phenomenon, with its range of causal processes, 
and the possible interrelations between them. It does not seek to isolate just one or a few causal processes and to hold everything else constant, as one does when modelling. Typically, this involves quite a large and complicated system, with many causal processes.

In addition, the causal impact of flows emerged clearly from all three case studies. Infection results from a flow of micro-organisms. Blood flow generates pressure differences that have causal consequences. And underlying the movement of tectonic plates is the magma flow in the Earth's upper mantle, resulting from convection currents [12].

In these natural sciences, theory development combines diverse types of evidence with hypothesis generation. Often the hypotheses arise out of description, generalisation and explanation, but sometimes more of an imaginative leap is involved. This is a cumulative process, not a one-off creation. It starts tentatively, then progresses, often with long delays, and possibly with some blind alleys. The first contribution is sometimes a causal idea and sometimes an observation or a group of observations.

In principle the process is iterative, alternating evidence with causally explanatory ideas, but it is not necessarily as neatly ordered as that description might imply. And even after the point is reached when the accumulated knowledge is secure - when one can safely say that the theoretical categories correspond to those of nature - further contributions continue to be added as new evidence is obtained, with the theory being extended, and modified if required.

Evidence is diverse. Experiments sometimes play an important role, but often the evidence is largely or entirely observational, especially in evolutionary biology, ecology and epidemiology, and in much of geology. Also, evidence is of two basic types [17]. One is "difference-making": for example, showing that cigarette smokers have a higher risk of lung cancer than non-smokers. The other aims at elucidating the mechanism - its composition/structure as well as how it works: e.g. the muscular composition and the valves in the human heart bring about the unidirectional pumping action. Diversity of types of evidence is a key strength: a large number of distinct types mean that they can be mutually corroborative.

Other features of empirically-based causal theories can be illustrated using the example of the germ theory of disease, which has these core concepts that concern the capacities of micro-organisms: they can (i) invade the body; (ii) cause disease; and (iii) multiply. Such a theory encompasses heterogeneity: the biology of rabies, anthrax, tuberculosis and malaria are quite different, but the core concepts remain applicable - with the details depending on the specific evidence on each disease. The theory is "allowed" to be incomplete in the sense that it does not have to encompass the whole domain - not all diseases are infections, and not all micro-organisms ("germs") cause disease - many are beneficial, and some are even essential. In addition, multiple causation is often a feature, and the theory includes an account of how the different causal factors interrelate - e.g. how nutritional status affects susceptibility to infection; in addition, infection can also affect nutritional status.

Several attributes distinguish empirically-based causal theories from models. A complete account of the theory may be quite complicated, whereas simplicity is a key virtue in models. In addition to the three features described in the previous paragraph, empirically-based causal theories have an ontic rather than an epistemic aim: they set out to accurately describe processes that occur in the real world. And they are phrased in the language of causation e.g. composition/structure, capacities and flows - not of mathematics.

Mathematical models can be developed that relate to specific components of the theory. For example, epidemiological models of infectious disease transmission in populations have been developed, that are different for different diseases, according to the evidence on each one. These can be quantitative, which is useful not only scientifically but also for policy. An important feature is that such models are nested within the broader causal theory: the theory informs the modelling of the causal processes that are included in the model, as well as containing the ones that are not included. This crucially means that scientists are aware of what has been omitted in each model.

\section{Causation in the Economy}

These examples suggest that scientific theories succeed well in explaining how the world works if they are focused on the causal processes that actually operate in the real world - attempting to align the theoretical causal concepts with those actually operating in the world. This may seem obvious, a tautology even, but it is not the only view in economic methodology. Friedman [18] put forward the view that explanation in economics could rely on "as if" theories, which precisely means substituting a theoretical notion for the real-life process. Although it is difficult to know how influential this view has been, according to Boland [19], "Friedman's essay is considered authoritative by almost every textbook writer who wishes to discuss the methodology of economics". Hammond [20] calls it "the methodological Bible" of most economists. Among economic methodologists, its reception has been less favourable [21], but it was thought important enough to justify a volume of essays to commemorate its fiftieth anniversary [22].

In contrast, more recent methodological work on economics tends to emphasise the importance of a causal account that is similar to the actually-occurring process, albeit in the context of discussing models. For example, Rol [9] praises models that capture something important such as a causal mechanism. Alexandrova and Northcott [3] argue that in principle, models can be successful at isolating the capacities that occur in the target system although they state that in practice this does not happen in economics (and in some biology). Grüne-Yanoff [4] 
emphasises the importance of the stability of the causal factor across different environments, which is an empirical question. Similarly, Rodrik [23] stresses causation: "economic models ... [are] simplifications designed to show how specific mechanisms work by isolating them from other, confounding effects. A model focuses on particular causes and seeks to show how they work their effects through the system ...".

\subsection{Specifying a Causal Rather than a Non-causal Mechanism}

The importance of specifying a causal mechanism rather than some non-causal argument might seem obvious. But it is not universal in economics.

An example is the analysis of how prices are set. In the 1930s, economists at Oxford held informal interviews with several business leaders, and found that they saw price setting in a completely different way to the model found in economics textbooks [24]. More recent reviews of the extensive literature on price setting have found that firms add a mark-up to the unit cost, using one of a variety of methods $[25,26]$. The size of the mark-up depends on what the market will bear (supply and demand), taking account of the trade-off between price and market share. The evidence shows that this is the causal process which occurs in the real world.

Standard theory ignores this, and introduces the concepts of marginal revenue and marginal cost, to fit with the methodological notion that economic reality depends on the intersection of curves with a particular functional form. This is a static, non-causal way of thinking, although the interaction of demand and supply can be interpreted causally [27]. Causal thinking would imply attention to the mechanism involved. In the case of price setting by firms, the textbook account was found to be completely meaningless to the business people actually setting the prices [24]. Nevertheless, the standard approach is to ignore that inconvenient fact, and even to invent the shape of one of the curves, the average cost curve, to suit the theory: it continues to be described as U-shaped, even though it has been known for several decades that this is rare in practice - at least among manufacturing firms, the proportion of firms that report a U-shaped cost curve has been estimated in the range of 5 to 11 percent $[28,29]$.

Of course, it is possible that the textbook notion has some merit in describing a quantitative constraint involved in firms' price setting - for example an upper or lower bound - even if it does not represent the causal process. If that is the case, why not say so? And provide the relevant evidence?

But this is not all: some economic theories deny that firms set prices at all! In general equilibrium theory, which is undeniably brilliant and beautiful, the assumption of a competitive market means that firms "take" prices, rather than setting them. That leaves unanswered the question of how prices are set. Various imaginative stories are provided, the classic one being Walras' idea of tatonnement. This is not intended to correspond with any actual reality, rather it is a story concocted to drive the abstract theory. Brilliance and beauty do not bring about correspondence with reality.

\subsection{Getting the Causal Mechanism Right}

Sometimes standard theory is found to conflict with the real world, leading to what is called a puzzle. In international economics, it has repeatedly been observed that people prefer to trade and to hold shares within their own country (the puzzle of home bias in trade and the puzzle of home bias in equity portfolios, respectively). There is also a strong tendency for investment to be funded by savings within the same country (the Feldstein-Horioka puzzle) [30]. These are in fact merely observations, not puzzles; the puzzle only arises if one starts by assuming that standard theory must be true. Or to put this in another way, the puzzle relates to the discrepancy between the theory and the reality it seeks - but fails - to explain.

Another variant is to take a story that may work in a limited context and assume it represents the way the world works more generally. The framework adopted in the international economics textbook by Obstfeld \& Rogoff [31], based on intertemporal modelling, and illustrates this. The central story is that a country that has a temporary income shortfall can borrow from another one, thereby avoiding a sharp contraction of consumption and investment. At other times, the roles are reversed. This could well apply in a situation such as a war or a natural disaster. However, its relevance to longer-term, more structural, imbalances is assumed by using this model outside that particular context. Its applicability there seems unlikely, and certainly needs to be demonstrated.

The issue of structural imbalances is the focus of the "Lucas puzzle". In a classic paper, Lucas [32] contrasted the theoretical prediction that all capital in rich countries should flow to poor ones, which have less capital and therefore higher returns, with his observation that this did not in fact occur. Subsequently, massive quantities of capital flowed from relatively poor countries such as China to rich ones such as the US - "uphill", because contrary to theory.

This phenomenon is actually quite straightforward to explain, and indeed is widely understood, e.g. by high-quality financial journalists [e.g. 33]. China generated huge profits in hard currency from its success in exporting, and rising living standards plus inadequate social security led to massive private saving too - altogether much more than the Chinese economy could invest, even with its famously high rate of investment. It flowed abroad, to purchase US Treasury bonds, real estate, corporations, and much else [34]. A similar pattern had been seen in previous successful East Asian countries, albeit on a smaller scale.

No mystery there, until one looks at the academic literature that tries to explain capital exports by such relatively low-income countries. To explain the discrepancy from what is "typical", i.e. standard theory, a 
widely-supported story is that the weak Chinese financial system prevents the expected borrowing by firms and by households [35-38]. From a mechanistic viewpoint, this idea involves a double error.

First, the standard idea that growing economies need to import capital does not apply to China, or indeed to most of the earlier dynamic East Asian export-led economies, which have a different development model from that assumed in standard theory, with different causal relations regarding capital flows [39]. Secondly, these authors are trying to explain the discrepancy from what is expected, rather than the phenomenon itself. In any case, they are factually wrong about this too: they postulate that financial development would allow China to borrow more easily, whereas the evidence indicates that "especially for most of the East Asian emerging market countries, ... more financial development leads to higher saving" [40, emphasis in the original].

In the case of Chinese capital exports, not only is the correct explanation obvious to almost everyone, it is also a coherent causal account that has many similarities to the practice of the natural sciences previously outlined. It is a causal explanation, that relies on the capacities of the key players - notably the capacity of Chinese industry to produce at very low unit cost, and hence to succeed in exporting. Flow is important - especially, tracing the source of the capital flow. In contrast, the traditional view based on Lucas [32] omits this, dealing only with the quantity of the already-existing capital stock and its implications for the rate of return as an incentive, and therefore gets the causal direction wrong [34].

The evidence is diverse: institutional analysis of the post-1978 Chinese reforms, data on capital - saving, profitability, etc. - and statistical data on the international capital flows. The account involves heterogeneity, because the East Asian development pattern does not fit with the "typical" pattern that the above-cited literature assumes should apply everywhere. In addition, the East Asian development pattern is itself heterogeneous, with the Chinese experience distinct in several ways [39]. And the explanation can encompass multiple causation: other factors are part of the overall causal account, including precautionary saving by Chinese households because social security provisions are weak, an exchange rate favourable to Chinese exports, and the desirability of rich-country assets such as US Treasury bills [34].

There are some examples of good practice in economics. One well-described causal account relates to the source of money in the modern economy. Most money is created when commercial banks make loans, and is destroyed when the loans are repaid. It is a side effect of bank lending, and depends on households' and businesses' demand for loans, together with banks' perceptions of the risk-adjusted prospect of profit. This is the location of the main causal impulse. ${ }^{1}$ The textbook account is wrong, both in saying

1 This account was standard in the early twentieth century, and was well that banks act simply as intermediaries, lending out savers' deposits, and that the central bank determines the quantity of loans and deposits in the economy by controlling the quantity of base money. The primary causal role is given to households' saving decisions in the first, and to the central bank in the second - and the latter is then alleged to be "multiplied up" to produce a much larger amount of broad money, the "money multiplier" idea which is commonly found in textbooks [41, 42].

The correct theory is based on a careful description of the actual behaviour of commercial banks, central banks and other participants, with special attention paid to the actually-occurring causal processes, and supported by statistical analysis. It is again "obvious", not only for this reason, but because participants (e.g. central bankers) have apparently been aware of it all along. It is causal, based on the specific capacities of banks that lend money, and of central banks etc. The importance of flow again emerges, because banks prefer to lend where there is collateral, so that they channel the flow of newly-created money primarily to existing assets rather than to businesses. Heterogeneity is important, because the causal processes depend on the institutional features of a modern financial system, and these can change over time; they are not present in all parts of the world. And multiple causation is again a feature, because central banks and governments also have roles that are important, albeit less central than bank lending.

\section{Capacities}

One equivalent concept to capacities in the natural sciences, such as those of micro-organisms, is the capacities of economic agents. Humans are of course highly heterogeneous, so that their capacities depend on levels of skill, training, experience, strength, diligence, etc. - usually summed up as human capital. (In fact, capacities can be heterogeneous in the natural sciences too: e.g. within a population of micro-organisms, some may be resistant to an antibiotic whereas others are sensitive to it. And variation within species is central to Darwin's theory of evolution.)

There are, however, at least three important differences. First, interaction between people is fundamental to human nature. This has many implications, some of which are briefly discussed below, in the section on System causation.

Secondly, humans tend to follow incentives. This makes incentives causal. But because it is only a tendency, rather than a deterministic relationship, the context is multi-causal - incentives are only one type of cause among others.

Thirdly, the exercise of human capacities involves both decision making and initiative. Decision making is well

understood by Schumpeter and others, but became displaced by other theories - for a historical review see Chick [73]. 
represented in economic theory - indeed, it is centre stage: standard theory is decision theory in algebraic form. But initiative is not, because the assumed optimization guarantees that a particular decision is taken, removing the role of human agency. ${ }^{2}$ The desire for a unique solution, whether or not it accurately represents reality, is dominant. This is seen as mathematical rigour - but is at the expense of scientific rigour, in the sense of doing justice to the actual causal processes. Heilbroner [43] may have had this in mind when he commented, "The prestige accorded to mathematics in economics has given it rigor, but, alas, also mortis".

Initiative involves also expectations that are uncertain, in the sense that no probability distribution can describe the possible outcomes, even in principle. The future is open-ended.

Agency, or the ability to take initiatives, is especially important in the context of new investment, innovation, etc. Much of this is done by firms. Firms prosper, stagnate, decline or disappear over the medium and long term, and their fate depends on the quality of initiatives undertaken, as well as on luck and on the economic environment. This is how the extreme heterogeneity of firms [44, 45] is generated. It has long been recognised that the growth of the firm is limited by its managerial capacity [46], and also that standard economic theory lacks "the entrepreneur", given that everything is seen as being automatically determined by optimization [47].

Schumpeter was responding to this when he introduced the concept of the entrepreneur, the type of person who is responsible for the creative destruction that characterises the modern economy. This has led to a very rich literature on innovation and entrepreneurship, but it has proved difficult to integrate this with traditional economic theory. Such integration would need to transform standard theory so as to focus on firms' new investment activity, and how this brings about economic change; it is not clear that this is feasible, given that optimization implies a unique course of action, removing the possibility of diverse initiatives.

The state also takes economically important initiatives. In addition to economic and monetary policy, it is important in a complementary role, supporting the economy e.g. by building roads. In some places, for example the United States after World War II, it has provided support for basic research and for more applied research and development, nurturing innovation. It has also acted entrepreneurially, taking on risk, and creating and shaping markets [48].

Capacities are important in the economy also in the sense of the capacities of various types of organisation. We have already met the specific capacities of commercial banks and central banks in the context of money creation, which denote the types of causation that they perform, e.g. commercial banks creating money. The term can also

2 Agency in this sense is different from its usage in the principal-agent view, in which the agent acts on someone else's behalf - indeed, it is almost the exact opposite. convey a more quantitative sense, as in the productive capacity of industry. ${ }^{3}$

\section{Flows and stocks}

An elementary observation about the economy is that it consists of flows. Students are typically introduced to economics with a flow diagram that depicts a whole economy with its component parts, e.g. households and firms, plus product markets and factor markets, and the flows between them: goods and services in one direction, and money in the other. This can be augmented by including also the state, the financial sector, and the overseas "sector".

Methods of documenting flows in the economy include input-output analysis [49], flow-of-funds analysis [50], and stock-flow consistent modelling [51]. These trace the physical or monetary flows, e.g. using interlocking balance sheets, but do not emphasise their causal efficacy.

Why are flows important from a causal viewpoint? We have already seen that the export of copious quantities of capital from China is simple to understand as long as one is aware of the source of all those funds. And if one switches perspective to the recipient country, the inflow of Chinese money has an impact, whether on domestic interest rates across the world, or on the growth of infrastructure as in large parts of Africa.

Similarly, the money created when banks lend money is a flow that has a causal impact. The incentives facing the banks strongly push them towards lending for the purchase of existing assets, because repossession is possible in the event of default. This causes asset price inflation, leading to a tendency towards bubbles and crashes, and an inter-generational imbalance in home ownership. On the other hand, if the flow were to firms for real-economy investment, it would lead to increasing productive capacity.

There is a more general and systematic causal role for flows, and also stocks, in the economy: buying power money in the hands of individuals and organisations that is available for purchasing something. It is similar to income (including transfers) and wealth, indeed these are the usual source of buying power, but here emphasising their causal impact on the economy. This focus is complementary to the more usual concern with the wellbeing or utility of individuals [52]. Inequality is not only a question of people's wellbeing and satisfaction, it also has economic consequences. ${ }^{4}$

3 Related to the causal concept of capacities, the capability approach seeks to provide an alternative to traditional welfare economics. In addition to the heterogeneity of human capital, it also emphasises the importance of agency, as well as stressing the non-economic dimension of human welfare. The agent's actions are seen in the light of that person's own values and goals [74-77]. Further discussion of this approach is beyond the scope of the present paper.

4 The concept of purchasing power is discussed by Bowles and Gintis [78], who relate it to power as a relationship, using Dahl's definition, "A has power over B to the extent that he can get B to do something that B would not otherwise do". However, the main focus of that paper is on the exercise of short-side power. For them, power is necessarily interpersonal, 
Again, this is an ancient concept in the history of economics, dating back at least to Adam Smith's observation that having money gives one the ability to "command" the labour of others, and continued - at the aggregate level only - in Keynes' concept of aggregate demand. Examples of its importance are everywhere. In attractive rural areas where the wage levels are generally low, holiday homes are bought by affluent urban dwellers, thus pricing out the local inhabitants. The spectrum of what is produced depends on the distribution of buying power a large number of rich people encourages the production and sale of luxury goods - spending power is "voting" power, with people having unequal numbers of votes. The buying power of firms makes it possible for them to pay the wages of their employees, thereby enabling production, and it also gives them the ability to transform the world, as a side effect of making investments that they hope will be profitable. Shareholders are able to have a strong influence on firms, and this ability stems from their having had the buying power to purchase the shares. At the macro level, when Chinese industry was booming, China's buying power led to a massive commodities boom throughout the world, a boom which is now subsiding along with the dynamism of Chinese manufacturing [52]. Buying power has a non-economic impact too, including on the political process, via lobbying, ownership of media outlets, think tanks, political influence, and the "revolving door" between officialdom and industry/commerce.

This leaves the question, what is it that flows? In one direction, it is money. In a modern economy, a large proportion of this occurs by the crediting of one account and the debiting of another - changes to an electronic record. In the other direction, the flow is not necessarily any more material than this. The purchase of a house, for example, involves the transfer of rights from one person to another. In fact, this is true more generally: even the sale of an object primarily involves claims and property rights. It corresponds with Sen's work on famines, in which the ability of an individual or household to obtain something depends on their entitlement. This can arise from (a) being able to trade something in exchange for it; (b) arranging its production using one's own resources; (c) producing it oneself with one's own labour; and (d) receiving it as a result of inheritance or other transfer [53].

Flows can be depicted in diagrams, as with the aggregate circular flow diagrams already mentioned. An alternative, which has the advantage of being quantitative as well as rigorous, is the use of interlocking balance sheets, as used for example in stock-flow consistent modelling [54].

Flows can accumulate to become stocks. And stocks can be the sources of flows - a stock is the propensity to cause a flow. It is the same relationship as between income and wealth. Buying power is not only a manifestation of the

rather than merely arising from the degree of strength that an individual or organisation has, and how this enables them to bring something about. For Bowles and Gintis, it also necessarily involves the threat and appropriate use of sanctions. flow, but also of the stock. This is often referred to as "deep pockets", in the context of the power to control a situation by virtue of having reserves of wealth, e.g. in the context of a large firm facing a legal case relating to an alleged misdeed of theirs such as pollution. Of course, all economists recognise this phenomenon, and it features in non-theoretical discourse. But it is neglected by standard theory.

\section{The Relationship of Decision Making with Flows}

Two principal elements in economic causation are thus agency causation (decision making, response to incentives, and initiative) and flows/stocks. The next question is, how are the two related?

Generally, decisions are concerned with the channelling of flows, or the interconversion of flows and stocks, e.g. the decision about how much money to save. What makes them relevant to economics is how they impact on the economy.

When a consumer decides to buy a washing machine, he channels some of his buying power to the seller of the washing machine. It is a choice, as standard economic theory maintains, but is possible only because the consumer is prosperous enough - a question not only of choice but also of ability - the availability of buying power [55]. Also, the washing-machine industry's existence and its size, depend on the number of people who have sufficient funds to afford to buy their product - in Adam Smith's term, "the size of the market". The aggregate causal effect of the flows directed towards washing-machine manufacturers by these purchasers is that it supports this industry. Again, this is something that all economists know, but is not incorporated into theory.

Similarly, initiatives tend to involve channelling flows. The most important type of initiative in modern economies is a real-economy investment, which typically involves two stages: the first is to spend money in order to buy something that will enhance future production and/or on Research and Development. In the second stage, over the medium term, the result will be a change in flows. This might be just the same type of production but at an increased volume (or even at the same volume, in the case of simple replacement). In the case of a process innovation, the flows may be similar to what was happening before, but now with a more favourable ratio between the outgoing flow of money and the incoming flow of inputs. A product innovation clearly involves new types of outflow of product in exchange for the inflow of money.

A technical invention is an example of an economically important initiative that does not necessarily involve flows at the first stage. But to be economically relevant, it must change the patterns of flow in the medium term. For example, an algorithm or item of new software may involve trivial flows in the first stage, but the second-stage transformative effect on subsequent flows of something 
like Google's search engine or the Uber app need no emphasis.

\section{The Relationship between Causation, Initiative and Power}

The concepts of causation and power are closely related, especially if one takes "power" in the sense of the ability to bring something about - the degree of strength. We have already seen how this works in the case of buying power. Initiative is another close relative, with its implication of bringing about something new.

Most forms of economic power are missing from economic theory, which focuses mainly on exchange between buyer and seller. Whilst this may not always be a relationship strictly of equals, e.g. if one of the parties has some degree of monopoly or monopsony power, no systematic inequality of power is involved. Bargaining power is also recognised, especially in the context of game theory. Apart from these two aspects, economic models do not generally recognise economic power.

Nevertheless, the idea of economic power cannot be dispensed with, if we want to understand the world. One frequently hears such phrases as the economic power of the United States [56], the shift of economic power from West to East [57], and corporate power [58]. What sense can be made of these phrases? Could they fit into a systematic account of how the economy works?

There is one other major context in which power is central to understanding the modern capitalist economy: within each firm there is an authority structure (although some firms are quite "horizontal", especially technology firms and associations of professionals such as lawyers and accountants). Authority is not quite the same as power; it indicates the ability to assign tasks to a subordinate, to allow them access to certain of the firm's resources (e.g. a machine) [59], to be responsible for their work, and to have some influence at least over their career prospects, e.g. their promotion or their dismissal. But it is different from, say, the use of violence or physical strength. One could say that authority is power that is regarded as legitimate.

The capitalist firm's authority structure typically has a management group in control and various levels or grades of labour below that. This hierarchy is not only the authority structure just described, it also involves monetary differentiation. This refers to the different rates of wages and salaries that different grades or types of worker receive. Both have implications for the degree of power that a worker has: authority denotes the degree of influence $\mathrm{s} / \mathrm{he}$ has within the firm, and pay grade denotes the extent of their buying power externally. A worker's wage level depends on her degree of bargaining power, especially her skills, experience, qualifications, etc., as well as their scarcity.

What are the sources of these various types of power? We have already seen that buying power depends on income as well as on accumulated wealth, and also on transfers (including borrowing), and that income depends on the level of human capital, albeit imperfectly.

In the case of the power relationship and the monetary hierarchy in the firm, it is partly a question of money: the firm has the wherewithal to pay its workers. That is primarily why they turn up for work. But more fundamentally, it is traceable to initiative. By having an idea that is potentially profitable, nowadays normally in the form of a business plan, company directors are able to attract the funds (if necessary ${ }^{5}$ ) for acquiring premises, paying workers, buying inputs, etc. This puts the directors in the position to direct operations, and to decide on the wage levels for the different grades of staff, sometimes in negotiation with workers, individually or collectively. This applies both to new firms - start-ups - and to existing firms, whose investment strategies embody the ideas that keep them in business and determine their degree of success.

In the literature, where I have used the term "directors", one commonly finds either "entrepreneurs" or "managers". The term "director" is preferable, not least because in many legal jurisdictions it is the directors who take responsibility for what the firm does. More important, we are here concerned with causation, the setting of the firm's direction, and the most natural word for the people who are doing this is the directors. In addition, there are problems with both of the other terms.

The issue with the term "entrepreneur" is that it is ambiguous. It is commonly used to refer to anyone who is self-employed. But it also often denotes someone who is successful in starting a business that then becomes an important firm that employs people, etc. If the two are confused, which happens frequently, then it implies that the sector of the economy that is self-employed is dynamic and makes a crucial contribution to the economy. The corollary is that policies should be developed to encourage more entrepreneurship. This neglects the considerable evidence that self-employment is associated with low productivity and an absence of dynamism [60].

Schumpeter introduced the concept of the entrepreneur as an antidote to the absence of human agency in standard theory, specifically in relation to innovation. He himself proposed a dual model of the economy, with the ultra-static "circular flow", plus the entrepreneurial sector that was responsible for creative destruction [61, 62]. However, he provided no causal account [63], mainly relying on the idea that radical change was brought about by a specific category of individuals, entrepreneurs - but without any explanation of, for example, why modern capitalist economies have not only an abundance of entrepreneurs in this sense of change-makers, but also that their innovations have had the aggregate effect of producing unprecedented economic growth and transformation.

The problem with the term "manager" is that it can sometimes be used in a way that downplays the importance

5 If they already start off with the necessary funds, this is an additional source of power - the amount of buying power that they possess. 
of what directors do. Managers can be hired and fired, they are not integral to the firm like directors are. This usage is especially entrenched in the literature on the relationship between the ownership and control of the firm, much of which promotes the doctrine of shareholder primacy, in other words, the view that those who have buying power and are willing to risk it are more important than those who are setting the direction of the firm [e.g. 64].

A further important aspect of economic power is in the relationship between firms. One way in which firms are heterogeneous is in their relative strength, which depends on their competitiveness. A major source of strength is unit costs: firms that can produce at lower cost have an advantage over their competitors; they can either cut prices while maintaining their profit margin, and expand market share at the expense of their rivals, or maintain a higher price and increase their profit [65]. Similar remarks apply to competitiveness deriving from a successful new product.

This relationship of relative strength could be described as a power relationship, but it is important to realise that no direct/personal relationship is necessary - a firm in China can put an Italian or a Zambian firm out of business simply by being able to sell at a lower price. The main source of the competitive edge is in the quality of their managerial capacity, specifically of their recent initiative(s), and their access to the necessary resources such as appropriate technology, workers and supply chains and the cost of these resources, plus luck.

\section{Information and Power}

We have seen that two major sources of economic power are agency/decision making/initiative, and buying power. This does not mean that they are the only sources; it is well known that information and knowledge are also sources of power. Insider trading is regarded as an unfair use of the power that information can confer.

One interesting example is the advantage of obtaining price information on stocks, especially fast-moving stocks, ahead of competitors. This became important with the increasing role of ICT in the financial sector in recent times. Traders who could do this were able to intercept orders from other, less professional traders. They could then block a trade at the previously-quoted price, and substitute it with one at a different price - one that was advantageous to themselves but inferior for the person whose bid had been intercepted $[66,67]$. The time advantage was measured in milliseconds or even in microseconds. This involved access to hardware that allowed a faster transmission time - it could be a direct, high-speed line from Chicago to New York, or even preferential locations close to the exchange where the trade was conducted, to minimise the cable length.

\section{System Causation}

Not all economic phenomena are caused by individual attributes - even if one includes initiative and uncertainty, and buying power etc. As previously stated, human beings are programmed to interact. An important consequence is that many economic phenomena are driven not by individual-level decision making and initiative, but by the consequences of human interaction. This is manifest as system causation.

One important example is the "price mechanism", the cornerstone of economic theory: the individual attributes of buyers and sellers become coordinated in such a way that an agreed price is possible. This is an instance of balancing (negative) feedback. It is important to note that this is the result of a combination of causal processes acting together, over time; it is not a static equilibrium, even if this is how it is typically conceptualised and modelled in standard economic theory.

The way that the price mechanism works is most clearly seen if something changes, such as a demand shock. If a product becomes more popular, e.g. as a result of a successful promotion campaign, a celebrity's endorsement, or news reports that it is beneficial in some way (e.g. it is a "super-food"), the price is likely to rise. This is an incentive for more suppliers to enter this market. As the supply grows, the price rise is choked off, and a new balance of demand and supply is reached.

If one allows that this particular type of feedback system can occur in the economy, by a combination of causes, it is a short step to recognising that a similar feedback-systems approach can account for many other well-recognised features of the modern economy. One example is balancing feedback with delay, leading to regular fluctuations, as is typical of real estate markets [68, pp. 698-707]. Another is the type of reinforcing (positive) feedback that leads to multiple equilibria and path dependence [69]. Reinforcing feedback can also cause bubbles and crashes [70], and played an important part in the recent financial crisis [71]. In addition, reinforcing feedback, in the form of an arms race between firms, is the reason that successful capitalist economies are dynamic [65, 71]. Furthermore, some aspects of the economy go beyond feedback, and display the features of complexity [e.g. 72].

\section{Conclusions}

Causation in the economy can be analysed using concepts such as capacities or mechanisms, and flows/stocks. They can fruitfully be incorporated in empirically-based causal theories, developed from the interplay between diverse sources of evidence and causal hypotheses, in a manner similar to that used in the natural sciences. Some modifications or additions are necessary, especially to deal with human agency - response to incentives, and initiative as well as decision making. The concept of causation is also related to that of economic power, at least in the sense of the ability to bring something about, with the possibility of extending it specifically into relative strength and power relations.

The analysis presented here has remained at the micro and meso (e.g. firm) level, even though some of the 
examples have involved the macroeconomy. The question of macro-level causation introduces further issues that are beyond the scope of the present paper, such as the issues of aggregation and fallacy of composition, of micro-foundations, and of methodological individualism. These will be the focus of further research.

\section{REFERENCES}

[1] Mäki, U. (2011). Models and the locus of their truth. Synthese, 180: 47-63. http://dx.doi.org/10.1007/s11229-009-9566-0

[2] Reiss, J. (2012). The explanation paradox. Journal of Economic Methodology, 19: 43-62. http://dx.doi.org/10.1080/1350178X.2012.661069

[3] Alexandrova, A., \& Northcott, R. (2013). It's just a feeling: why economic models do not explain. Journal of Economic Methodology, 20(3): 262-267.

[4] Grüne-Yanoff, T. (2013). Genuineness resolved: a reply to Reiss' purported paradox. Journal of Economic Methodology, 20: 255-261.

[5] Hands, D.W. (2013). Introduction to symposium on the explanation paradox. Journal of Economic Methodology, 20: $235-236$

[6] Hausman, D.M. (2013). Paradox postponed. Journal of Economic Methodology, 20: 250-254. http://dx.doi.org/10.1080/1350178X.2013.828868

[7] Mäki, U. (2013). On a paradox of truth, or how not to obscure the issue of whether explanatory models can be true. Journal of Economic Methodology, 20: 268-279. http://dx.doi.org/10.1080/1350178X.2013.828869

[8] Reiss, J. (2013). The explanation paradox redux. Journal of Economic Methodology, 20: 280-292. doi:10.1080/1350178X.2013.828874

[9] Rol, M. (2013). Reply to Julian Reiss. Journal of Economic Methodology, (20)3: 244-249.

[10] Sugden, R. (2013). How fictional accounts can explain. Journal of Economic Methodology, 20: 237-243.

[11] Marshall, A. (1920). Principles of economics (8th ed.). New York: Cosimo.

[12] Joffe, M. (2017a). Causal theories, models and evidence in economics - some reflections from the natural sciences. Cogent Economics \& Finance, http://dx.doi.org/10.1080/23322039.2017.1280983

[13] Morgan, M.S. (2012). The world in the model: how economists work and think. Cambridge: Cambridge University Press.

[14] Cartwright, N. (1989). Nature's capacities and their measurement. Oxford: Oxford University Press.

[15] Machamer, P., Darden, L., \& Craver, C.F. (2000). Thinking about mechanisms. Philosophy of Science, 67: 1-25.

[16] Illari, P.M., \& Williamson, J. (2012). What is a mechanism? Thinking about mechanisms across the sciences. European Journal of Philosophy of Science, 2: 119-135.

[17] Russo, F., \& Williamson, J. (2007). Interpreting causality in the health sciences. International Studies in the Philosophy of Science, 21: 157-170.

[18] Friedman, M. (1953). The methodology of positive economics, reprinted in D.M. Hausman (Ed.). 1994. The philosophy of economics: an anthology, $2^{\text {nd }}$ edition, Cambridge: Cambridge University Press.

[19] Boland, L. (1979). A critique of Friedman's critics. Journal of Economic Literature, 17: 503-522.

[20] Hammond, J.D. (1992). The problem of context for Friedman's methodology. Research in the history of economic thought and methodology, W.J. Samuels (Ed.), volume 10, pages 129-147. Greenwich, CT: JAI Press

[21] Mayer, T. (1993). Friedman's methodology of positive economics: a soft reading. Economic Inquiry, 31: 213-223.

[22] Mäki, U. (Ed.) (2009). The methodology of positive economics: reflections on the Milton Friedman legacy. Cambridge: Cambridge University Press.

[23] Rodrik, D. (2015). Economics rules: why economics works, when it fails, and how to tell the difference. Oxford: Oxford University Press.

[24] Hall, R.L., \& Hitch, C.J. (1939). Price theory and business behaviour. Oxford Economic Papers, 2: 12-45.

[25] Downward, P. (1999). Pricing theory in Post-Keynesian economics: a realist approach. Cheltenham: Edward Elgar.

[26] Lee, F.S. (1999). Post Keynesian price theory. Cambridge: Cambridge University Press.

[27] Hausman, D.M. 1992 Essays on philosophy and economic methodology. Cambridge: Cambridge University Press, especially chapter 11 .

[28] Eiteman, W.J., \& Guthrie, G.E. (1952). The shape of the average cost curve. American Economic Review, 42: 832838.

[29] Blinder, A.S., Canetti, E., Lebow, D., \& Rudd, J. (1998) Asking about prices: a new approach to understanding price stickiness. New York: Russell Sage Foundation.

[30] Obstfeld, M., \& Rogoff, K. (2000). The six major puzzles in international macroeconomics: is there a common cause? NBER Macroeconomics Annual, 15: 339-412.

[31] Obstfeld, M., \& Rogoff, K. (1996). Foundations of international macroeconomics. Cambridge, MA: The MIT Press.

[32] Lucas, R.E. Jnr. (1990). Why doesn't capital flow from rich to poor countries? American Economic Review, 80 (2): 92 96.

[33] The Economist, 29 March 2014. On cloud nine trillion, page 65; and Up, up and away, page 75 - respectively at http://www.economist.com/news/china/21599806-our-asiaeconomics-editor-takes-his-leave-less-worried-many-his-pe ers-about-frailties and

http://www.economist.com/news/finance-and-economics/2 1599774-higher-inflation-may-be-needed-leave-extra-low-i nterest-rates-behind-up-up-and

[34] Joffe, M. (2017b). Why does capital flow from poor to rich countries? - the real puzzle. Real-World Economics Review, issue no. 81, http://www.paecon.net/PAEReview/issue81/Joffe81.pdf

[35] Prasad, E., Rajan, R., Subramaniam, A. (2007). The paradox of capital. Finance and Development (IMF), 44 (1). http://www.imf.org/external/pubs/ft/fandd/2007/03/prasad. htm.

[36] Sandri, D. (2010). Growth and capital flows with risky entrepreneurship. IMF Working Paper WP/10/37. https://www.imf.org/external/pubs/ft/wp/2010/wp1037.pdf.

[37] Song, Z., Storesletten, K., Zilibotti, F. (2011). Growing like China. American Economic Review, 101 (1): 196-233. http://pubs.aeaweb.org/doi/pdfplus/10.1257/aer.101.1.196.

[38] Alfaro, L., Kalemli-Ozcan, S., \& Volosovych, V. (2014). 
Sovereigns, upstream capital flows and global imbalances. Journal of the European Economic Association, 12 (5): $1240-1284$.

http://web.b.ebscohost.com.iclibezp1.cc.ic.ac.uk/ehost/pdfv iewer/pdfviewer?vid=6\&sid=f9227ab6-5421-4eb6-b4c6-e9 44f0f08e77\%40sessionmgr120\&hid=118.

[39] Studwell, J. (2014). How Asia works: success and failure in the world's most dynamic region. London: Profile Books Ltd.

[40] Chinn, M., \& Ito, H. (2008). Global current account imbalances: American fiscal policy versus East Asian savings. Review of International Economics, 16: 479-498.

[41] Ryan-Collins, J., Greenham, T., Werner, R., \& Jackson, A. (2012). Where does money come from? - a guide to the UK monetary and banking system. London: New Economics Foundation.

[42] McLeay, M., Radia, A., Thomas, R. (2014). Money creation in the modern economy. Bank of England Quarterly Bulletin, Q1: 14-27.

[43] Heilbroner, R.L. (1979). Modern economics as a chapter in the history of economic thought. History of Political Economy, 11 (2): 192-198.

[44] Bartelsman, E.J., \& Doms, M. (2000). Understanding productivity: lessons from longitudinal microdata. Journal of Economic Literature, XXXVIII: 569-594.

[45] Grazzi, M. (2012). Export and firm performance: evidence on productivity and profitability of Italian companies. Journal of Industry, Competition and Trade, 12 (4): 413 444.

[46] Penrose, E.T. (1959). The theory of the growth of the firm. Oxford: Blackwell.

[47] Demsetz, H. (1983). The neglect of the entrepreneur. In: J. Ronen (Ed.) Entrepreneurship. Lexington, MA: Lexington Books.

[48] Mazzucato, M. (2013). The entrepreneurial state. London \& New York: Anthem Press.

[49] Miller, R.E., \& Blair, P.D. (2009). Input-output analysis: foundations and extensions, $2^{\text {nd }}$ edition. Cambridge: Cambridge University Press.

[50] Dawson, J.C. 1996. Flow-of-funds analysis: a handbook for practitioners. Abingdon: Routledge.

[51] Caverzasi, E., \& Godin, A. (2014). Post-Keynesian stock-flow-consistent modelling: a survey. Cambridge Journal of Economics, 39: 157-187.

[52] Joffe, M. (2017c). The neglect of buying power in traditional economic theory, and its practical implications. Advances in Economics and Business, 5(8): 435-439.

[53] Sen, A.K. (1981). Poverty and famines: an essay on entitlement and deprivation. Oxford: Oxford University Press.

[54] Godley, W., \& Lavoie, M. (2007). Monetary Economics: An Integrated Approach to Credit, Monev, Income, Production and Wealth. London: Palgrave Macmillan.

[55] Brown, J.A.C., \& Deaton, A. (1972). Surveys in applied economics: models of consumer behaviour. The Economic Journal, 82: 1145-1236.

[56] Steele Gordon, J. (2005). An empire of wealth: the epic history of American economic power. London: Harper Perennial.

[57] The Economist, 24 September 2011. A game of catch-up. http://www.economist.com/node/21528979
[58] Parkinson, J.E. (1993). Corporate power and responsibility: issues in the theory of company law. Oxford: Clarendon Press.

[59] Rajan, R.G., \& Zingales, L. (1998). Power in a theory of the firm. The Quarterly Journal of Economics, 113 (2): 387 423.

[60] GEM. (2014). Global Entrepreneurship Monitor. 2014 Global Report. http://gemconsortium.org/report

[61] Schumpeter, J.A. (1980) [1911 in German, 1934 in English]. The theory of economic development. New Brunswick, NJ: Transaction Publishers

[62] Schumpeter, J.A. (1992) [1942]. Capitalism, socialism and democracy. London: Routledge.

[63] Joffe, M. (2013). What causes creative destruction? In: A Pyka, E.S. Andersen (Eds.), Long term economic development, economic complexity and evolution. Berlin Heidelberg: Springer-Verlag.

[64] Jensen, M.C., \& Meckling, W.H. (1976). Theory of the firm: managerial behavior, agency costs and ownership structure. Journal of Financial Economics, 3 (4): 305-360.

[65] Joffe, M. (2011). The root cause of economic growth under capitalism. Cambridge Journal of Economics, 35: 873-896.

[66] Ding, S., Hanna, J., \& Hendershott, T. (2014). How slow is the NBBO? A comparison with direct exchange feeds. The Financial Review, 49: 313-332.

[67] Lewis, M. (2014). Flash boys. New York: W.W. Norton and Company.

[68] Sterman, J.D. (2000). Business dynamics: systems thinking and modeling for a complex world. Boston, MA: Irwin McGraw-Hill.

[69] Arthur, W.B. 1994. Increasing Returns and Path Dependence in the Economy. Ann Arbor, Michigan: University of Michigan Press.

[70] Shiller, R.J. (2005). Irrational exuberance. $2^{\text {nd }}$ edition. Princeton, NJ: Princeton University Press.

[71] Joffe M. Submitted. Equilibrium, instability, growth and feedback in economics. In: B.C. Dangerfield, R. Cavana, D. Wheat, \& O. Pavlov. (Eds.) Feedback Economics: the contribution of system dynamics to economic analysis.

[72] Mandelbrot, B., \& Hudson, R.L. (2008). The (mis)behavior of markets: a fractal view of risk, ruin, and reward. New York: Basic Books.

[73] Chick, V. (2005). Lost and found. Some history of endogenous money in the twentieth century. In G. Fontana and R. Realfonzo (Eds.), The monetary theory of production (pp. 53-66). London: Palgrave Macmillan.

[74] Sen, A. (1992). Inequality reexamined. New York: Russell Sage Foundation.

[75] Sen, A. (2001). Development as freedom. Oxford: Oxford University Press.

[76] Anand, P., Santos, C., \& Smith, R. (2009). The measurement of capabilities. In K. Basu and R. Kanbur (Eds.) Arguments for a better world: essays in honor of Amartya Sen, 1, Oxford: Oxford University Press.

[77] Nussbaum, M. (2011). Creating Capabilities: The Human Development Approach. Cambridge, MA: Harvard University Press.

[78] Bowles, S., \& Gintis, H. (1998). Power in competitive exchange. In: S. Bowles, M. Franzini, U. Pagano (Eds.) The politics and economics of power (pp. 10-24). London: Routledge. 